\title{
Pengamatan Efek Pratritmen Tandan Kosong Sawit sebelum Proses Konversi Biogas dengan Analisis Mikroskopi
}

\section{Microscopy Analysis to Observe the Pretreatment Effect of Oil Palm Empty Fruit Prior to Biogas Process Conversion}

\author{
IIN PARLINA \\ Pusat Teknologi Lingkungan, Badan Pengkajian dan Penerapan Teknologi \\ Gedung 820 Geostech, Kawasan Puspiptek Serpong, Tangerang Selatan \\ Email: iin.parlina@bppt.go.id
}

\begin{abstract}
Conversion of lignocellulosic biomass such as Oil Palm-Empty Fruit Bunch (OP-EFB) into bioenergy is a promising solution to mitigate the impact of climate change and avoid an energy crisis that have been globally anticipated. The abundance amount of OP-EFB as a biomass waste from oil palm processing in Indonesia has opened more chance to produce bio-energy and other valuable products without having competition with the food sector. It has a high content of cellulose and hemicellulose that can be processed generating bio-energy such as biogas or bioethanol. However, to be processed into bioenergy, and other products, EFB should be pretreated first to break the recalcitrant characteristic and increase the yield and conversion rate. Alkaline pretreatment is widely known for its effectivity on lignin removal to open more access of the lignocellulose, especially for the Anaerobic Digestion (AD) process. There is some way to assess the performance of a pretreatment method prior to the $A D$ process, for example by using chemical analysis. However, a visual assessment also can be applied. Therefore, microscopy analysis is a powerful tool to examine and observe the microstructural or morphological change from the pretreatment process. This research's objective is to perform microscopy observation on the OP-EFB component's changes during the low concentrated alkaline pretreatment using $\mathrm{NaOH}$ and mixture of $\mathrm{NH}_{4} \mathrm{OH}$ and $\left(\mathrm{NH}_{4}\right)_{2} \mathrm{CO}_{3}$. The result from using CLSM shows the process of delignification, while SEM shows 3 major visual changes i.e. delignification, silica bodies removal, surface degradation and the enhanced bacteria's affinity to the OP-EFB's surface.
\end{abstract}

Keywords: Microscopy analysis, Oil palm empty fruit bunch, alkaline pretreatment, Anaerobic Digestion, visual changes

\begin{abstract}
ABSTRAK
Konversi biomassa lignoselulosa seperti Tandan Kosong Sawit (TKS) menjadi bioenergi adalah solusi yang menjanjikan untuk mengurangi dampak perubahan iklim dan menghindari krisis energi yang telah diantisipasi secara global. Jumlah kelimpahan TKS sebagai residu dari proses produksi minyak kelapa sawit telah membuka banyak peluang untuk menghasilkan bioenergi dan produk nilai lainnya tanpa bersaing dengan sektor pangan. TKS memiliki kandungan selulosa dan hemiselulosa tinggi yang dapat diproses menghasilkan bioenergi seperti biogas atau bioetanol. Namun, untuk diproses menjadi bioenergi, dan produk lainnya, substrat ini harus dipratritmen terlebih dahulu untuk mengatasi karakteristik rekalsitransi yang menjadi penghambat utama dalam proses biokonversi. Pratritmen dengan menggunakan reagent basa (alkalin) secara luas dikenal karena efektifitasnya pada penghilangan lignin untuk membuka lebih banyak akses lignoselulosa, terutama untuk proses produksi biogas (AD). Terdapat beberapa cara untuk mengevaluasi kinerja Pratritmen sebelum proses AD, misalnya dengan analisis kimia juga pengamatan visual dengan menggunakan mikroskop. Observasi visual menekankan adanya perubahan mikrostruktur atau morfologi dari proses pratritmen sehingga bisa menjadi metode untuk menjelaskan secara fisik apa yang terjadi dalam tataran mikroskopis. Tujuan dari penelitian adalah melakukan analisis mikroskopi dengan menggunakan confocal dan SEM pada TKS sebelum dan setelah dilakukan pratritmen dengan alkalin $\mathrm{NaOH} 6 \%$ dan campuran $\mathrm{NH}_{4} \mathrm{OH}$ dengan $\left(\mathrm{NH}_{4}\right)_{2} \mathrm{CO}_{3}$ 10\% selama 24 jam juga TKS hasil pratritmen yang digunakan untuk proses produksi biogas. Hasil dari Confocal memperlihatkan adanya perubahan dari TKS sebelum pratritmen dibandingkan dengan setelah pretreatmen yaitu terjadinya proses delignifikasi, sementara hasil dari SEM memperlihatkan 3 perubahan visual utama yang dapat dianalisis yaitu penghilangan silika, degradasi permukaan dan peningkatan afinitas bakteri pada permukaan TKS yang dilakukan pratritmen.
\end{abstract}

Kata kunci : analisis mikroskopi, tandan kosong kelapa sawit, pratritmen alkalin, Anaerobic Digestion, perubahan visual 


\section{PENDAHULUAN}

Indonesia merupakan salah satu negara penghasil kelapa sawit terbesar di dunia. Hal ini dibuktikan dengan banyaknya perusahan perkebunan serta perusahaan pengolah kelapa sawit termasuk di dalamnya perusahaan oleokimia, minyak goreng, biodiesel. Industri kelapa sawit memberikan kontribusi yang cukup signifikan bagi perekonomian nasional. Selain merupakan penyumbang devisa ekspor non migas terbesar, industri kelapa sawit Indonesia dilakukan dengan sistem tata kelola lingkungan yang baik menuju industri kelapa sawit Indonesia yang lestari atau sustainable palm oi(1).

Dalam prosesnya, industri minyak kelapa sawit menghasilkan beberapa residu yang dianggap sebagai limbah yang berpotensi menjadi beban pencemaran lingkungan jika tidak dikelola dengan baik. Namun, sebenarnya jika diolah secara maksimal dengan menggunakan teknologi yang tepat, limbah tersebut akan memberikan nilai lebih yang signifikan bagi industri.

Salah satu jenis limbah padat dari proses produksi minyak kelapa sawit yaitu tandan kosong (TKS), merupakan jenis biomassa yang mengandung lignin, selulosa, dan hemiselulosa ${ }^{2}$ yang memiliki potensi besar seiring berkembangnya teknologi biorefineri untuk mengubah limbah lignoselulosa menjadi bahan bakar seperti bioetanol, biogas, dan bahan bakar lainnya. Kandungan TKS ini bisa dilihat dari Tabel 1 di bawah

Tabel 1. Komposisi tandan kosong sawit dari berbagai sumber ${ }^{(2,3)}$

\begin{tabular}{lcc}
\hline Komponen & $\mathbf{\%}^{(2)}$ & $\mathbf{\%}^{(3)}$ \\
\hline Glukan & 32.4 & 42.85 \\
\hline Xilan & 6.8 & 24.01 \\
\hline Galaktan & 1.0 & 0.1 \\
\hline Mannan & 0.9 & 42.5 \\
\hline Acid Soluble Lignin & 23.0 & 18.5 \\
\hline Acid Insoluble Lignin & 1.6 & 11.7 \\
\hline Abu & & 0.52 \\
\hline Lainnya & & 20.92 \\
\hline
\end{tabular}

Berdasarkan Tabel 1 di atas dapat dilihat bahwa kandungan holoselulosa (Glukan, Xilan, Galaktan, Mannan) adalah cukup tinggi dalam TKS yang membuatnya potensial untuk dikonversi menjadi bioenergi berupa bioetanol dan biogas. Hanya saja konfigurasi dari molekul penyusun gula ini bersama pengikatnya yaitu lignin belum diketahui secara pasti sehingga upaya efektif untuk mendegradasinya masih belum diketahui secara komprehensif. Selain itu, seperti halnya biomassa lignoselulosa pada umumnya, untuk dikonversi menjadi biogas, TKS harus menjalani pratritmen terlebih dahulu untuk kemudahan bakteri mencernanya dan mengkonversi kandungan selulosa dan hemiselulosa menjadi biogas.

Terdapat banyak metode pratritmen yang dapat digunakan untuk membuka komponen lignoselulosa dan meningkatkan daya konversinya menjadi biogas ${ }^{(4)}$. Salah satu pratritmen yang dinilai efektif adalah dengan menggunakan reagent basa misalnya $\mathrm{NaOH}^{(5)}$, $\mathrm{NH}_{4} \mathrm{OH}^{(6)}, \mathrm{KOH}$, dan reagent basa yang lainnya ${ }^{(2)}$. Untuk mengevaluasi kinerja dan efektifitasnya dalam meningkatkan perolehan biogas, pada umumnya dilakukan metode kimia misalnya pengukuran lignin, selulosa, dan hemiselulosa sebelum dan sesudah pratritmen. Metode yang banyak diterapkan adalah metode yang dikembangkan oleh National Renewable Energy Laboratory (NREL)-USA ${ }^{(7)}$. Namun, selain analisis kimia, pengamatan visual dengan menggunakan mikroskop juga dinilai dapat memberikan gambaran bagaimana efek pratritmen dalam mengurangi lignin atau juga hemiselulosa yang ada di dalam biomassa. Beberapa penelitian yang dilakukan di luar Indonesia untuk biomassa seperti jerami gandum, jerami padi, switchgrass dan lainnya telah menunjukan adanya perubahan visual yang terjadi akibat pratritmen yang dapat dikaitkan dengan peningkatan kinerja konversi biorefineri.

Mikroskop adalah salah satu alat yang bisa diandalkan untuk memahami struktur dan fungsi dari berbagai komponen biomassa yang berbeda dari jaringan ke makromolekul. Baru-baru ini, mikroskop telah muncul sebagai alat yang menjanjikan untuk membantu proses memahami proses yang terjadi pada pratritmen dan proses biorefinery setelahnya (biogas atau bioetanol). Hal ini karena mikroskop mampu memberikan, visualisasi tentang ultrastruktur biomasa. Namun tidak hanya itu, dengan menggunakan preparasi sampel yang tepat dan didukung dengan penguasaan metode pencitraan yang baik, mikroskop kini bisa diandalkan juga untuk melakukan pengukuran dan kuantifikasi, dekonstruksi struktural dinding sel tanaman setelah pratritmen baik secara biologis, kimia dan atau fisik.

Pendekatan mikroskopi telah berkontribusi pada penentuan secara akurat dari struktur makromolekul untuk sistem biologis kompleks, yang mengarah pada penjelasan tentang ultrastruktur seluler dan fungsinya. Teknik mikroskopi dapat digunakan untuk menetapkan, pada tingkat molekuler, arsitektur dinding sel serta efektivitas biomassa pratritmen lignoselulosa untuk produksi biofuel(8). Adapun jenis mikroskop yang sudah pernah digunakan 
untuk evaluasi visual efek dari proses pratritmen misalnya confocal (Confocal Laser S Microscopy/ CLSM), Scanning electron microscopy (SEM), transmission electron microscopy (TEM), Light Microscopy (LM), dan Atomic Force Microscopy (AFM)

Pilihan platform mikroskopi yang sesuai akan bergantung pada proses seluler yang akan diamati. Pada proses biogas misalnya, memvisualisasikan mikroba ke selulosa dari biomasa akan cukup sulit jika hanya menggunakan mikroskop cahaya tradisional karena biomasa selulosa pada umumnya bersifat buram dan dapat menghalangi transmisi cahaya $^{(9)}$.

Mikroskop cahaya konvensional (wide-field) tidak cocok untuk pemeriksaan bagian biomasa yang lebih tebal dari sekitar 10-20 $\mu \mathrm{m}$ karena terbatasnya fokus lensa yang ada yang disebabkan oleh gangguan dari bagian spesimen di atas dan di bawah bidang fokus. Hal ini akan menghasilkan gambar dengan kualitas buruk ${ }^{(10)}$.

Confocal atau CLSM mampu memberikan informasi penting tentang konsentrasi dan distribusi spasial fluorophore dalam sampel, karena molekul ini memiliki waktu peluruhan fluoresensi karakteristik tergantung pada lingkungan mikro. Mengenai efek pratritmen dalam biomassa, CLSM sebelumnya digunakan untuk menyelidiki degradasi dan redistribusi lignin, redistribusi xilan, pembengkakan dinding sel dan keterpaparan selulosa ${ }^{(11)}$. Prinsip confocal atau CLSM adalah untuk menghindari hilangnya fokus dengan memindai spesimen dengan sumber penerangan yang kecil dan terkontrol secara tepat dan detektor yang disinkronisasi sedemikian rupa sehingga sampel secara optik 'dipotong'.

Selain dengan menggunakan cahaya fluoresense, pengamatan dengan menggunakan metode elektron-mikroskopis juga dapat digunakan. Metode ini telah dikembangkan selama bertahun-tahun untuk menganalisis distribusi lignin dalam elemen kayu yang berbeda ${ }^{(12)}$. Dua jenis mikroskop elektro yang bisa digunakan adalah SEM dan TEM. SEM adalah alat yang sangat bisa diandalkan dalam penyelidikan permukaan struktur sampel biologis $^{(13)}$. Sementara TEM menekankan pada kedalaman dari komponen biomassa yang diamati.

Ketika penelitian mengenai biokonversi biomassa lignoselulosa lebih banyak mengevaluasi perubahan kimia yang terjadi seperti perubahan kadar holoselulosa dan lignin, maka penelitian ini mengambil sudut pandang untuk melihat efek-efek fisik mikrostruktural yang disebabkan oleh pratritmen dengan landasan berpikir atas peran mikroskopi yang bisa digunakan untuk mengungkap struktur secara mikro. Sehingga dengan adanya kelebihan yang dimiliki masing-masing metode mikroskopi, dilakukan pengamatan dan evaluasi seberapa jauh perubahan visual yang terjadi yang bisa menjelaskan mekanisme pratritmen dan dampaknya pada proses biorefinery yang dalam hal ini biogas. Sehingga dalam penelitian ini dilakukan pratritmen dengan menggunakan reagent basa yaitu dan campuran $\mathrm{NH}_{4} \mathrm{OH}$ dengan $\left(\mathrm{NH}_{4}\right)_{2} \mathrm{CO}_{3}$ dan lalu dilakukan evaluasi perubahan visual yang terjadi pada TKS setelah pratritmen dan ketika proses $A D$.

\section{BAHAN DAN METODE}

\subsection{Bahan dan Alat}

Tandan kosong sawit (TKS) diperoleh dari residu pohon kelapa sawit (Elaesis guineensis), setelah proses ekstraksi minyak. TKS pada penelitian ini dikeringkan, digiling, lalu diayak untuk mendapatkan ukuran partikel yang sama.

Proses pratritmen dilakukan dengan metode perendaman dengan menggunakan labu erlenmeyer, dilanjutkan dengan proses produksi biogas secara Alat pratritmen dan alat biogas. Instrumen mikroskop yang digunakan untuk menganalisis adalah CLSM dan SEM.

\subsection{Metode}

\subsubsection{Pratritmen dan Pemrosesan biogas}

TKS yang tidak diberi perlakuan dan praperlakuan dari berbagai metode pratritmen alkalin dianalisis menggunakan CLSM dan SEM. Zat alkalin yang digunakan untuk pratritmen adalah $\mathrm{NaOH} 6 \%$ dan campuran $\mathrm{NH}_{4} \mathrm{OH}$ $\left(\mathrm{NH}_{4}\right)_{2} \mathrm{CO}_{3} 10 \%$ selama 24 jam. Setelah TKS dipratritmen, TKS kemudian diproses secara anaerob menggunakan bakteri inokulum dari digester utama dari Pullman Wastewater Treatment Plant. Sistem biogas yang digunakan adalah mesophilic yaitu dengan menggunakan temperatur $37^{\circ} \mathrm{C}$ dan sistem batch dengan bantuan alat respirometer untuk pengamatan jumlah biogas yang dihasilkan

\subsubsection{Pengamatan dengan Mikroskopi}

Alasan penggunaan confocal dalam penelitian ini adalah sebagai berikut: CLSM atau mikroskop confocal memiliki kelebihan berupa resolusi yang lebih tinggi, karena adanya penghapusan cahaya di luar fokus, sensitivitas, serta kemampuan untuk menghasilkan bagian optik serial sampel fluorescent massal, termasuk jaringan tanaman, diikuti oleh analisis pencitraan tiga dimensi. Selanjutnya, pengurangan latar belakang fluoresensi dan peningkatan sinyal-kegambar tercapai, yang mengarah ke struktur kontras dan struktur yang terdefinisi lebih tinggi. Melihat hal ini, CLSM adalah metode yang 
sangat baik untuk menyelidiki struktur jaringan internal dalam bentuk 3D. Mikroskop confocal menjadi salah satu metode alternatif potensial untuk menilai degradabilitas enzim di situ dari dinding sel biomassa dengan menggabungkan rekonstruksi citra 3-D dan pengukuran kuantitatif(14).

Scanning electron microscopy (SEM) merupakan alat yang sangat bisa diandalkan dalam mengevaluasi perubahan struktural pada resolusi tinggi dalam dinding sel setelah pratritmen biomassa. Hal ini karena SEM mampu menggambarkan fitur anatomi dan degradasi pada permukaan sel dan nano-resolusi permukaan biomassa ${ }^{(14)}$.

Untuk menghasilkan gambar yang diinginkan, pelaksanaan metode mikroskopi yang digunakan untuk analisis dalam penelitian ini dibagi menjadi tiga bagian.

Metode pertama adalah menganalisis perubahan morfologi TKS berupa gambaran permukaan struktur dan membandingkannya dengan TKS yang tidak dipratritmen. Untuk mendapatkan perbandingan ini, cukup menggunakan prosedur standar dasar dari penggunaan SEM yakni terdiri dari dua langkah, yaitu proses pelapisan emas dan dilanjutkan dengan SEM (Hitachi S-570 dengan 20 kv).

Metode kedua adalah menganalisis perubahan visual lignin dan selulosa menggunakan sistem confocal Zeiss LSM 510. Persiapan sampel termasuk fiksasi menggunakan Glutaraldehid, diikuti dengan langkah dehidrasi menggunakan etanol dan resin LR White Spesimen kemudian diwarnai dengan $10 \mu \mathrm{M}$ Acridine Orange.

Metode ketiga adalah menganalisis struktur permukaan TKS setelah dilakukan pratritmen dan proses biogas. Metode ini ditujukan untuk melihat efek dari pratritmen terhadap pertumbuhan dan aktivitas bakteri. Persiapan melibatkan tahap fiksasi menggunakan 2\% Paraformaldehyde, 2\% Glutaraldehyde, dan $0,1 \mathrm{M}$ fosfat ${ }^{(15)}$. Untuk mencegah pembentukan kristal, sampel diperlakukan dengan sukrosa dan cacodylate. Setelah itu, sampel siap untuk pengeringan beku yang dilakukan dalam waktu semalam. Sampel beku lalu dilapisi emas sebelum pencitraan SEM.

\section{HASIL DAN PEMBAHASAN}

Dari berbagai penelitian biorefineri dari biomasa menjadi bioenergi, pada umumnya evaluasi kinerja dan keberhasilan efektifitas sebuah metode pratritmen dinyatakan dengan hasil analisis kimia untuk membandingkan kandungan lignin, selulosa, dan hemiselulosa yang ada dalam biomassa sebelum dan setelah pratritmen. Hasil perubahan kimiawi ini kemudian dikaitkan dengan perolehan proses biokonversi biomassa tersebut sehingga pada umumnya dilakukan pencarian relevansi antara perubahan kimiawi yang terjadi setelah pratritmen dengan hasil biokonversinya misalnya jumlah bioethanol dan biogas yang dihasilkan. Namun selain menggunakan analisis kimia, evaluasi pratritmen dengan menggunakan analisis visual juga bisa digunakan. Telah banyak penelitian mengenai penggunaan SEM dalam mengamati terjadinya perubahan struktur permukaan biomassa setelah dilakukannya pratritmen, namun belum ada penelitian yang berfokus pada pengamatan visual untuk proses inti biorefineri setelah pratritmen dilakukan. Misalnya untuk konversi biogas, belum ada dilakukan penelitian dan pengamatan visual bagaimana kerusakan yang terjadi akibat pratritmen menghasilkan dampak yang signifikan dalam peningkatan produksi biogas. Apakah kemudian dengan peningkatan luas permukaan, bakteri akan semakin kuat pelekatannya, ataukah dengan begitu bakteri akan semakin baik efektiftas proses mencerna dan mengkonversi? Demikian pertanyaanpertanyaan yang kemudian diupayakan untuk dijawab dalam penelitian ini.

\subsection{Analisis dengan menggunakan Confocal}

Sebagaimana bisa dilihat dalam Gambar $1 \mathrm{di}$ bawah ini bahwa, TKS yang dilakukan pratritmen dan TKS yang tanpa pratritmen memiliki perbedaan penyerapan warna fluoresens dari CLSM. Terlihat bahwa lignin yang dicitrakan berwarna orange dapat dilihat pada middle lamela dan secondary layer (S2). Pada gambar TKS tanpa pratritmen, tampak warna oranye yang lebih mencolok daripada TKS dengan pratritmen. Sudut sel pada middle lamellae berpendar lebih terang daripada lamella tengah yang berdekatan dengan variasi kecerahan dari sel ke sel. Hal ini relevan dengan yang telah dilakukan oleh $\mathrm{F}$ Xu et all yang melakukan penelitian terhadap biomass ${ }^{(16)}$. Oleh karena absorbansi lignin terhadap sinyal cahaya berbanding lurus dengan konsentrasi lignin yang terkandung dalam biomassa, hal ini mengindikasikan terjadinya pengurangan lignin pada komponen TKS yang dilakukan pratritmen ${ }^{(16)}$. Hal ini didukung dengan adanya hasil evaluasi kimia untuk mengukur kadar lignin TKS sebelum dan sesudah pratritmen dilakukan yakni $23.99 \%$ menjadi $15.24 \%$.

Distribusi material dinding sel antara berbagai jenis sel tumbuhan dapat berkontribusi secara signifikan terhadap variasi dalam degradabilitas biomasa dengan komposisi kimia yang sama secara keseluruhan tetapi anatomi yang berbeda. Tandan kosong sawit bisa memiliki perbedaan degradabilitas dengan jerami padi dan sebagainya yang menyiratkan perlunya pengetahuan secara komprehensif mengenai ultrastruktur biomasa yang untuk memahaminya 
bisa dibantu dengan menggunakan mikroskopi confocal. Bahkan, pembagian optik dari bagian tebal biomasa dengan menggunakan confocal menyediakan metode yang memperkirakan volume material dinding sel yang ada di bagian jaringan sebelum dan sesudah pratritmen, dan memvisualisasikan jaringan tanaman menggunakan rekonstruksi citra 3-D. Lebih jauh lagi, penggunaan CLSM memungkinkan pengukuran degradabilitas dilakukan pada sel in situ yang dapat memberikan informasi yang lebih cepat dan relevan daripada yang dapat diperoleh dengan fraksinasi mekanis dari jaringan. Hal ini akan memegang peranan sangat penting bagi pengamatan hasil pratritmen dalam proses biorefinerinya misalnya proses konversi biogas di mana bakteri hidup memakan biomasa secara langsung berada di bawah pengamatan mikroskop. Sehingga hasil yang ditampilkan akan menjadi lebih valid(11).

Untuk mencapai hal tersebut, pengukuran kuantitatif volume dinding sel dan ketebalan

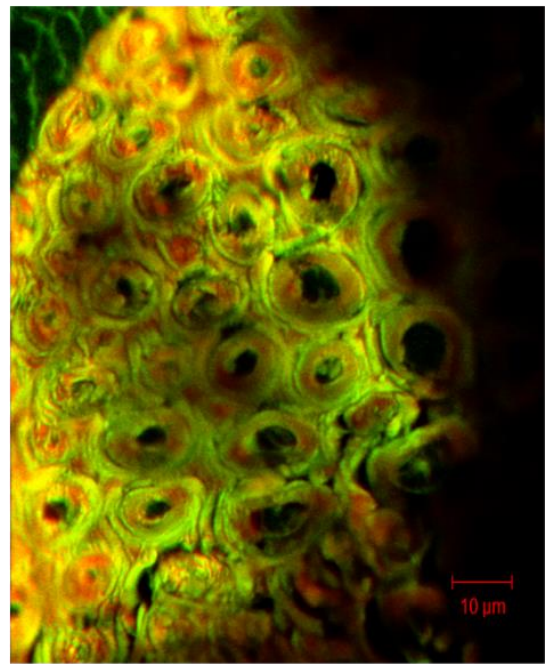

(i) dinding sel memiliki potensi metode untuk kuantisasi degradabilitas dinding sel dalam rangka evaluasi unjuk kerja sebuah metode pratritmen $^{(10)}$.

Sejauh ini, pada proses biorefineri bioethanol, metode CLSM telah digunakan untuk memvisualisasikan bagian tebal yang diambil dari maize dan barley ruas sebelum dan sesudah degradasi dengan enzim pengurai dinding sel ${ }^{17}$.

Namun di balik kelebihan yang ada, memang patut disadari bahwa kualitas hasil pengambilan gambar akan tergantung pada absorptivitas molekul lignin yang cukup sensitif terhadap berbagai faktor struktural. Khususnya keberadaan ikatan ganda atau gugus karbonil dapat menyebabkan peningkatan absorptivitas yang cukup besar. Untuk determinasi yang benar, absorptivitas dari jaringan morfologi yang berbeda harus persis sama; selain itu harus ditentukan dalam eksperimen terpisah ${ }^{(12)}$.

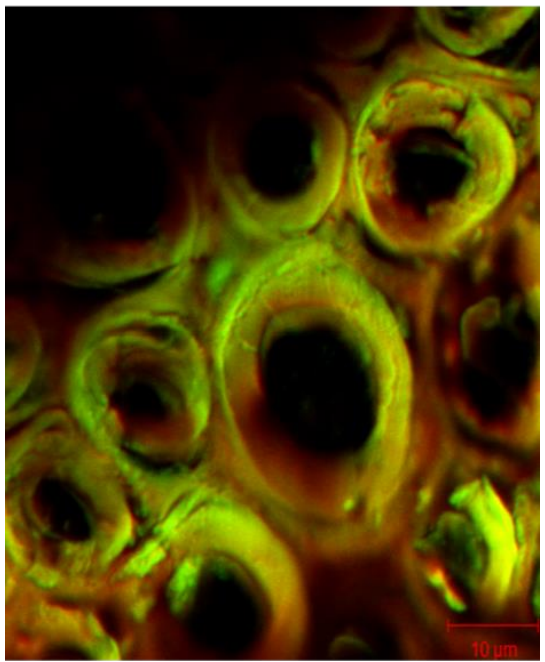

(ii)

Gambar 1. Hasil pencitraan tandan kosong sawit dengan menggunakan miroskop confocal tanpa pratritmen (i) dengan pratritmen menggunakan reagen campuran $\mathrm{NH}_{4} \mathrm{OH}$ dengan $\left(\mathrm{NH}_{4}\right)_{2} \mathrm{CO}_{3} 10 \%$ (ii)

\subsection{Analisis dengan menggunakan SEM}

Pada penelitian ini dapat dilihat dari Gambar 2 di bawah ini bahwa terjadi kerusakan permukaan biomasa TKS oleh reagent basa jika dibandingkan permukaan sebelum dilakukan pratritmen yang permukaannya cross section atau penampang melintang yang jauh lebih mulus. Selain itu, dapat dilihat juga bahwa tandan kosong sawit memiliki sejenis badan silika yang disebut sebagai phytolit yang fungsinya baru diketahui hanya sebagai lapisan luar pelindung pembuluh dari TKS. Badan silika ini yang kemudian nantinya diketahui memiliki peran yang penting ketika terjadi penghilangan pada proses pratritmen yang dilanjutkan dengan proses biogas.
Sebagai efek pratritmen akibat kontak dengan reagent basa yang dianggap memiliki kemampuan melarutkan lignin, peningkatan kerusakan dan kekasaran dari permukaan biomasa TKS diperkirakan akan memperluas area untuk dilekati oleh bakteri. Selain itu, kerusakan yang ada akan mengurangi rigiditas TKS untuk dicerna bakteri secara lebih baik.

Selain adanya kerusakan permukaan pada area cross section yang ditunjukan pada Gambar 3 (i), terdapat kerusakan badan silika yang ada di permukaan TKS. Dapat dilihat bahwa silika yang hilang akan meninggalkan area berlubang sesuai dengan diameter silika yang dikandungnya, area ini kemudian diketahui disebut sebagai silica crater. Fungsi silica crater ini kemudian diketahui pada hasil analisis mikroskopi untuk subtrat TKS 
yang sudah dilakukan penetrasi dengan bakteri melalui proses anaerobik biogas seperti yang ditunjukan pada Gambar 4.

Dari gambar 4 inilah kemudian bisa dilihat uniknya analisis mikroskopi yang tidak bisa dijelaskan oleh analisis kimiawi bahwa bakteri memiliki afinitas atau ketertarikan untuk mencerna area silica crater terlebih dahulu sebagai langkah awal mencerna bagian biomasa TKS yang lainnya. Hal ini terlihat dari adanya lubang di sekitar silica crater. Hipotesis dari kejadian ini adalah bahwa area di bawah badan silika yang kemudian menjadi silica crater setelah pratritmen terjadi relatif mudah dicerna dibandingkan dengan bagian lain di badan TKS.
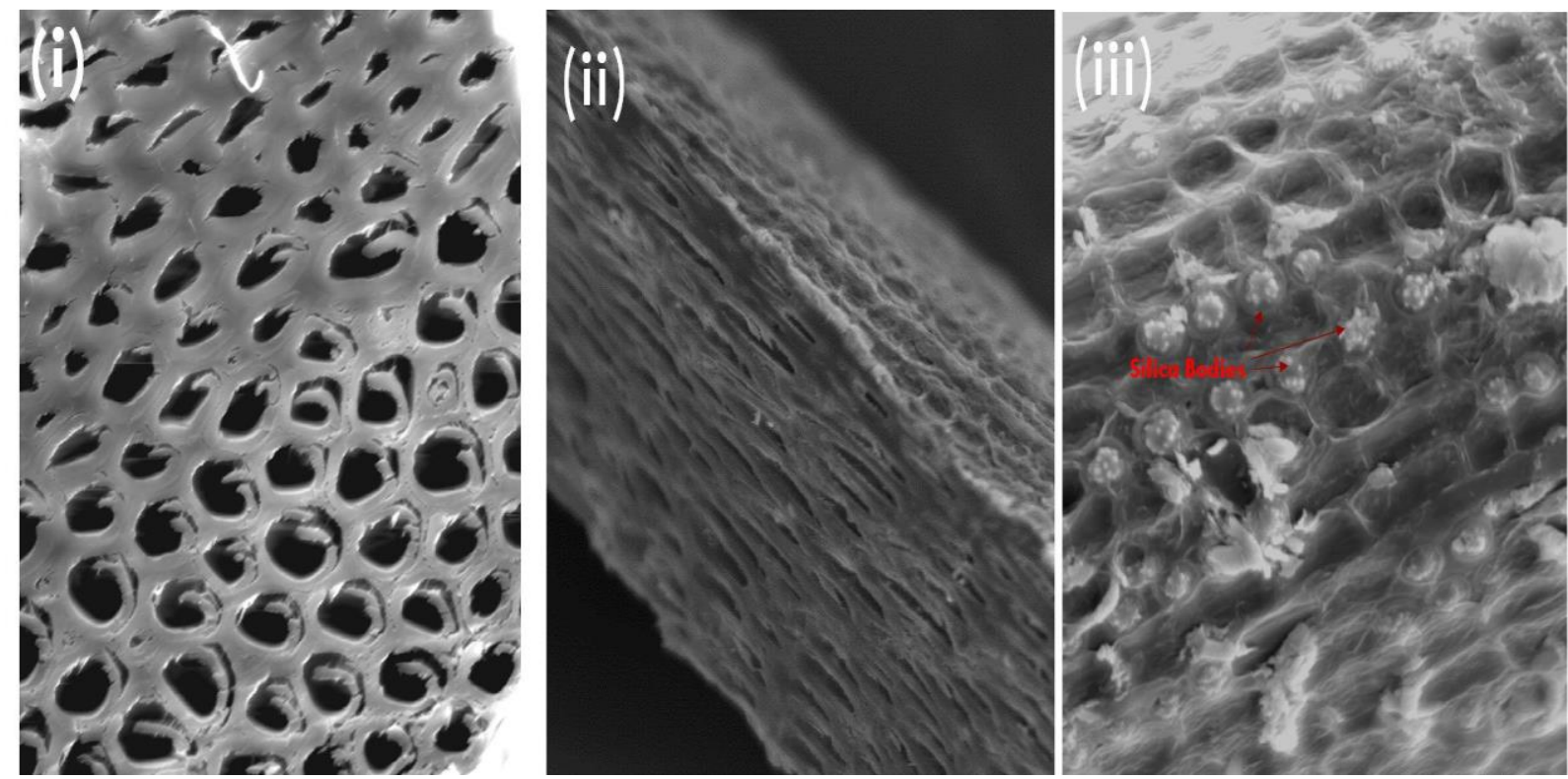

Gambar 2. Area penampang melintang TKS Sebelum pratritmen (i) dan (ii) yang mencerminkan kemulusan permukaan, serta (iii) yang memperlihatkan badan silika TKS
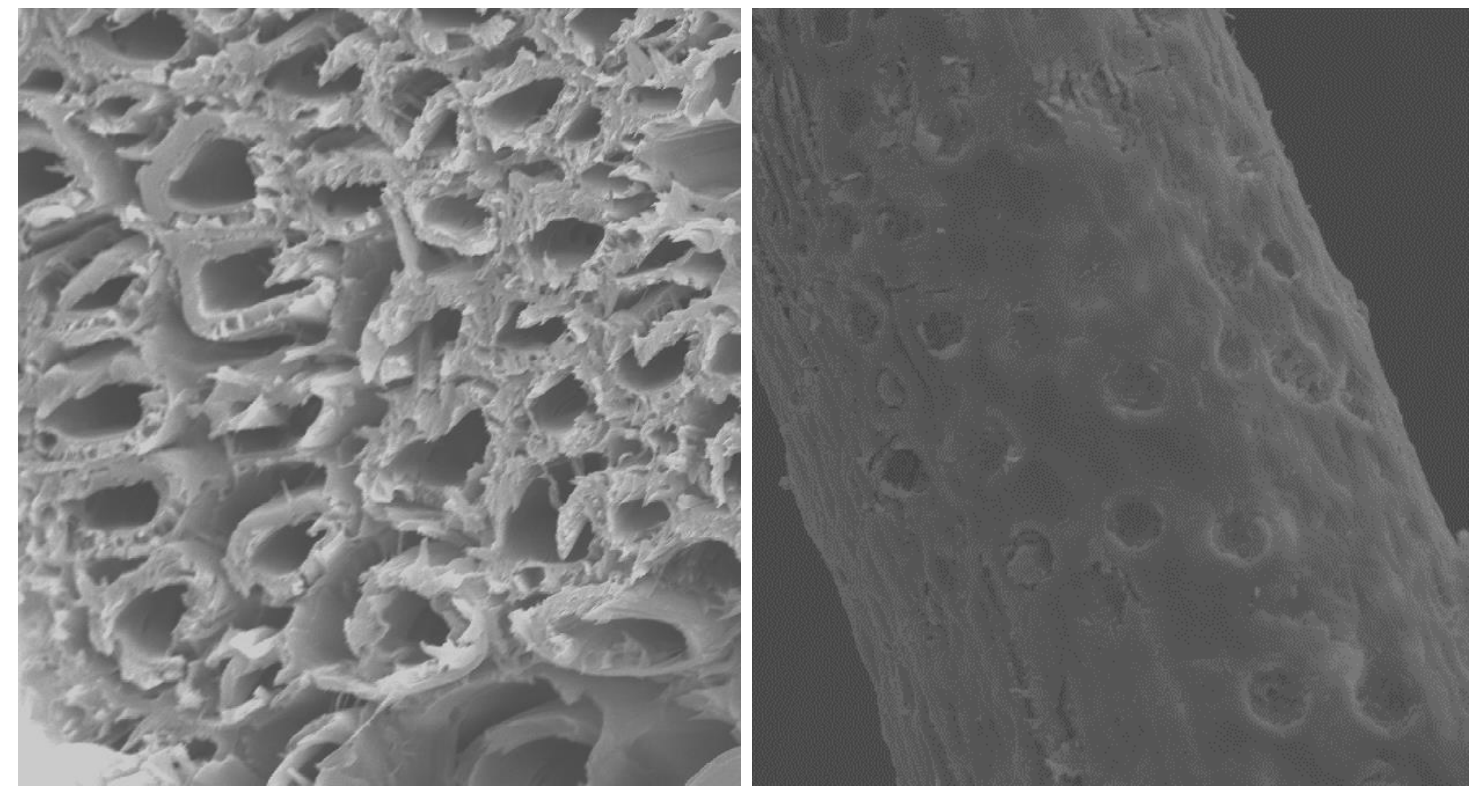

Gambar 3. Area cross section TKS setelah dilakukan pratritmen dengan menggunakan $\mathrm{NaOH} 6 \%$ berat/berat TKS (i), serta permukaan TKS yang dilakukan pratritmen campuran $\mathrm{NH}_{4} \mathrm{OH}$ dengan $\left(\mathrm{NH}_{4}\right)_{2} \mathrm{CO}_{3} 10 \%$ (ii) 

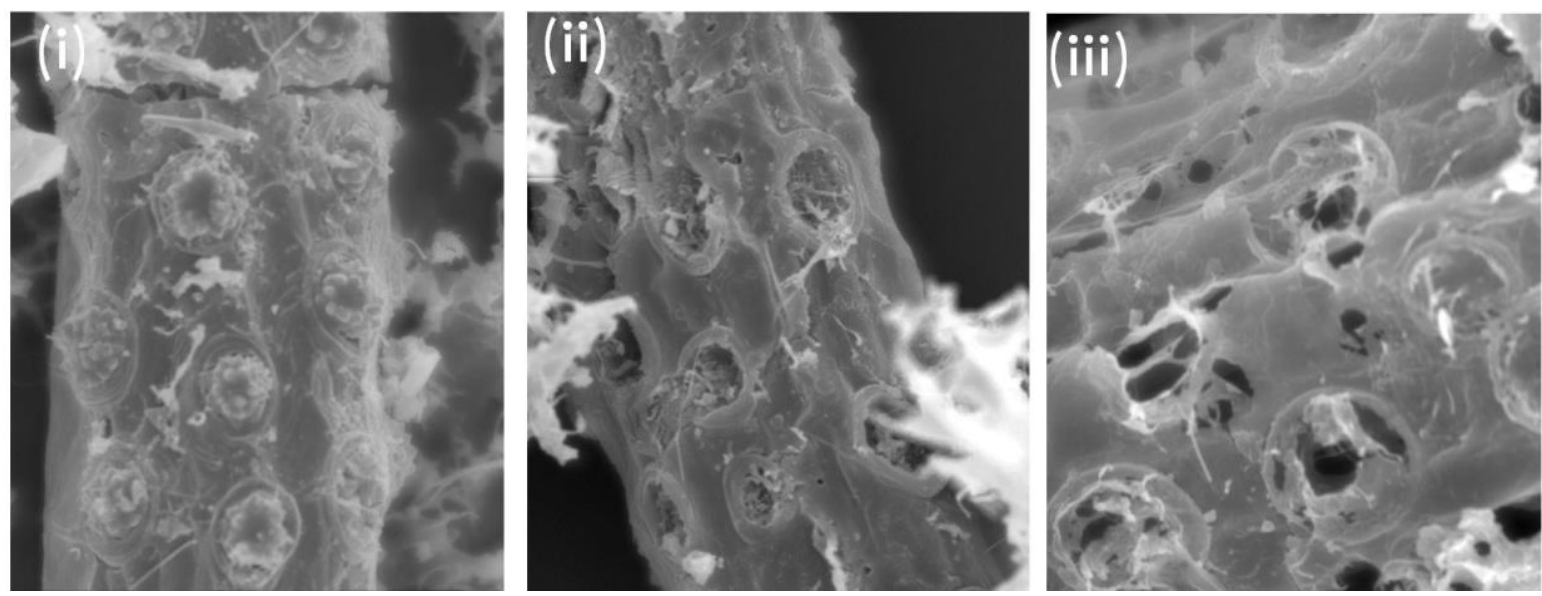

Gambar 4. Mikrograf SEM dari TKS setelah dilakukan Proses AD selama 10 hari. (i) permukaan TKS yang tidak dipratritmen, (ii) dan (iii) permukaan TKS dipratritmen dengan campuran $\mathrm{NH}_{4} \mathrm{OH}$ dengan $\left(\mathrm{NH}_{4}\right)_{2} \mathrm{CO}_{3} 10 \%$
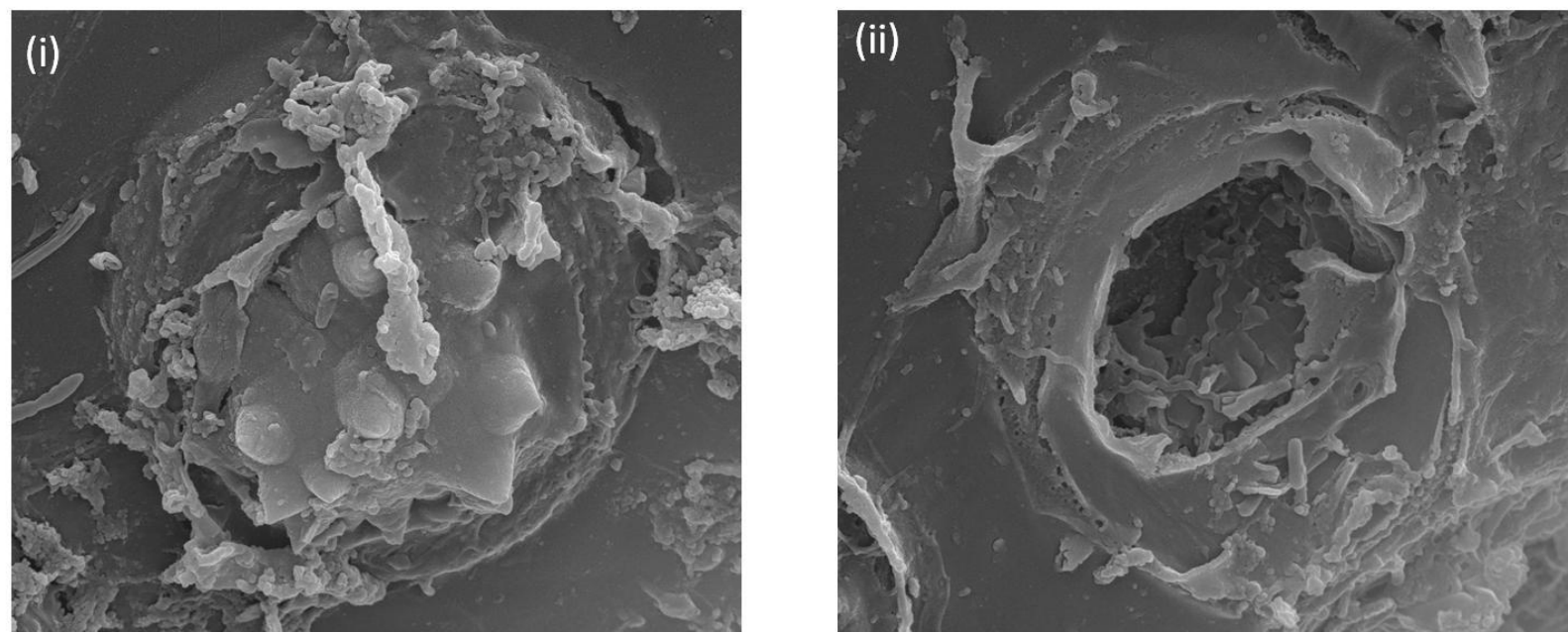

Gambar 5. Perbedaan pelekatan bakteri pada permukaan TKS yang masih memiliki badan silika

(i) dibandingkan dengan TKS yang sudah kehilangan badan silika (ii)

Hipotesis yang dijelaskan oleh mikrograf ini yang kemudian menjadi teori alasan terjadinya peningkatan biogas yang terjadi dalam penelitian sebesar $22.7 \%$ antara TKS yang tanpa pratritmen dengan yang dilakukan pratritmen campuran $\mathrm{NH}_{4} \mathrm{OH}$ dengan $\left(\mathrm{NH}_{4}\right)_{2} \mathrm{CO}_{3} 10 \%$.

Selain itu, hal lain yang dapat ditunjukan melalui analisis visual ini adalah seperti pada Gambar 4 yan bisa memperlihatkan bahwa SEM mampu menangkap citra dari biofilm yang terbentuk di area sekitar biomasa yang memegang peranan penting dalam proses konversi biogas oleh bakteri.

Kemudian dengan menggunakan perbesaran lebih besar lagi, dapat dilihat bahwa terdapat lebih banyak bakteri yang melekat pada area silica crater ini (Gambar 5). Hipotesis terkait alasan ketertarikan bakteri pada area ini akan lebih baik dibuktikan dengan penelitian selanjutnya.

Lebih jauh terkait dengan pengamatan proses inti yaitu biogas, SEM yang memiliki resolusi visualisasi mikrobial yang lebih tinggi daripada teknik pencitraan lain, biasanya $3,5 \mathrm{~nm}$, juga mampu mengukur data dalam tiga dimensi diharapkan mampu untuk bisa menampilkan penampilan TKS ketika dilekati oleh bakteri. Namun, teknik ini menggunakan pelarut bergradasi (alkohol, aseton, dan xilena) untuk secara bertahap mendehidrasi spesimen sebelum pemeriksaan, karena air hidrasi tidak kompatibel dengan vakum yang digunakan dengan berkas elektron ${ }^{(13)}$. Selain itu, aktifitas cellulosome yang diindikasikan dan dihipotesiskan memegang peranan penting dalam proses konversi biomasa lignoselulosa juga dapat diobservasi lebih jauh lagi dengan menggunakan SEM.

Penggunaan Confocal dan SEM seperti yang disebutkan sebelumnya bisa dibawa kepada proses kuantifikasi dengan menggunakan metode-metode analisis grafik yang dihasilkan oleh mikroskopi. Misalnya delignifikasi bisa diukur berapa presentase pengurangan bila 
membandingkan sebelum dan setelah dilakukannya pratritment. Demikian halnya dengan aplikasi SEM, daya kerusakan yang terjadi pada permukaan bisa dikuantifikasi dan dikalibrasi dengan melakukan pendekatan matematis dari citra yang dihasilkan. Juga dengan peningkatan afinitas bakteri, bisa dilakukan perhitungan jumlah bakteri yang melekat, atau juga bisa melihat biofilm yang ada serta menganalisis silica crater yang dihasilkan melalui pratritmen. Hanya saja, dalam penelitian awal ini, proses kuantifikasi berdasarkan analisis mikroskopi seperti pengurangan ketebalan dinding sel, atau jumlah bakteri yang melekat, juga luas area biomasa TKS yang terdegradasi akibat pratritmen atau pada saat proses biogas belum dapat dilakukan.

Selain itu, juga bisa dilakukan pembandingan antara pratritmen dengan menggunakan reagent basa yang lebih tinggi konsentrasinya atau lebih lama waktu kontak perendamannya sehingga bisa dievaluasi mana parameter pratritmen yang lebih efektif. Dalam hal penelitian ini, dilakukan penelitian pendahuluan yang memodifikasi proses pratritmen dengan menggunakan parameter yang berbeda sehingga muncul nilai optimal yang kemudian dilanjutkan dengan proses analisis mikroskopi untuk parameter terpilih.

Aplikasi penggunaan analisis mikroskopi sebagai alat untuk mengevaluasi parameter dan kinerja sebuah pratritmen di lapangan memang akan membutuhkan waktu dan alat yang banyak. Sehingga sarannya adalah menggunakan kombinasi analisis kimia dan kemudian mengevaluasi hasil dari analisis kimia dengan menggunakan analisis visual kuantitatid mikroskopi. Selain itu juga, untuk penelitian di masa depan, bisa dilakukan cara menggabungkan berbagai pendekatan mikroskopi, seperti CLSM, TEM, SEM dan AFM, untuk memahami, secara rinci, bagaimana perubahan struktural pada dinding sel, yang disebabkan oleh pratritmen biomassa, meningkatkan aksesibilitas selulosa, yang sangat penting dalam hal penelitian dan perkembangan untuk produksi bioenergi. Tapi penelitian ini diharapkan bisa menjadi awal dasar untuk observasi lebih dalam mengoptimasi kekuatan mikroskop untuk mengungkap lebih jauh mengenai apa yang terjadi dalam proses pa pratritmen dan bagaimana pengaruhnya terhadap proses biorefinery setelahnya. Misalnya optimasi Confocal dan SEM dalam hal pengukuran dan kuantifikasi dari pencitraan 3 Dimensi yang bisa dilakukan. Juga bisa dibandingkan antara 1 jenis pratritmen dengan pratritmen lainnya atau satu biomasa dengan biomasa lainnya, atau juga menggabungkan hasil analisis satu jenis mikroskop dengan mikroskop jenis lainnya.

\section{KESIMPULAN}

Pengamatan mikroskopi pada perubahan komponen lignoselulosa selama pratritmen alkalin dengan menggunakan reagen $\mathrm{NaOH} 6 \%$ dan campuran $\mathrm{NH}_{4} \mathrm{OH}$ dengan $\left(\mathrm{NH}_{4}\right)_{2} \mathrm{CO}_{3} 10 \%$ selama 24 jam menunjukkan bahwa: ada 4 perubahan visual utama yang dapat dianalisis yaitu penghilangan bagian silika/Phytolit, degradasi permukaan dan perubahan morfologi pada area cross section, penghapusan lignin (dari confocal), dan peningkatan afinitas bakteri ke permukaan TKS. Perubahan ini mendukung analisis kimia bahwa reagent basa bisa digunakan sebagai upaya perlakuan sebelum proses biorefineri utama yaitu biogas dilakukan. Dari hasil pengamatan visual juga dapat dilihat adanya penghilangan badan silika yang dapat meningkatkan perlekatan permukaan bakteri.

Dari penelitian ini juga dapat dilihat bahwa ada pengamatan visual yang akan memberikan penjelasan lebih baik mengenai dampak dan proses pratritmen biomasa TKS serta pengaruhnya terhadap proses biogas setelahnya yang bisa memberikan gambaran yang tidak mampu dicapai oleh hanya mengandalkan analisis kimia.

\section{PERSANTUNAN}

Peralatan dan bahan kimia yang digunakan untuk analisis mikroskopi dalam proyek ini disediakan oleh Franceschi Microscopy dan Imaging Center (FMIC) -Washington State University. Terima kasih khusus kepada Christine Davitt, Valerie Lynch-Holm, Dan Mullendore, sebagai instruktur hebat, dan Naisi Li. Terima kasih kepada Dr. Shulin Chen dan beasiswa Fulbright yang membuat saya melaksanakan penelitian ini. Juga kepada Direktur PTL Dr. Rudi Nugroho dan Kabagpro PTL Dr. Muhammad Hanif atas izinnya mengikuti program ini.

\section{DAFTAR PUSTAKA}

1. Tan, K. T., Lee, K. T., Mohamed, A. R., \& Bhatia, S. (2009). Palm oil: Addressing issues and towards sustainable development. Renewable and Sustainable Energy Reviews, 13(2), 420-427. https://doi.org/10.1016/J.RSER.2007.10.001

2. Nieves, D. C., Karimi, K., \& Horváth, I. S. (2011). Improvement of biogas production from oil palm empty fruit bunches (OPEFB). Industrial Crops and Products, 34(1), 10971101.

https://doi.org/10.1016/j.indcrop.2011.03.02 2 
3. Yunus, R., Salleh, S. F., Abdullah, N., \& Biak, D. R. A. (2010). Effect of ultrasonic pre-treatment on low temperature acid hydrolysis of oil palm empty fruit bunch. Bioresource Technology, 101(24), 97929796.

https://doi.org/10.1016/j.biortech.2010.07.07 4

4. Zheng, Y., Zhao, J., Xu, F., \& Li, Y. (2014). Pretreatment of lignocellulosic biomass for enhanced biogas production. Progress in Energy and Combustion Science, 42(1), 3553. https://doi.org/10.1016/j.pecs.2014.01.001

5. Pavlostathis, S. G., \& Gossett, J. M. (1985). Alkaline treatment of wheat straw for increasing anaerobic biodegradability. Biotechnology and Bioengineering, 27(3), 334-344.

https://doi.org/10.1002/bit.260270319

6. Gao, A. H., Bule, M. V., Laskar, D. D., \& Chen, S. (2012). Structural and Thermal Characterization of Wheat Straw Pretreated with Aqueous Ammonia Soaking. Journal of Agricultural and Food Chemistry, 60(35), 8632-8639

7. A. Sluiter, B. Hames, R. Ruiz, C. S., \& J. Sluiter, D. Templeton, and D. C. (2011). Determination of Structural Carbohydrates and Lignin in Biomass: Laboratory Analytical Procedure (LAP). Golden. https://doi.org/10.1007/s00449-014-1243-0

8. Sant'Anna, C., Costa, L. T., Abud, Y., Biancatto, L., Miguens, F. C., \& de Souza, W. (2013). Sugarcane cell wall structure and lignin distribution investigated by confocal and electron microscopy. Microscopy Research and Technique, 76(8), 829-834. https://doi.org/10.1002/jemt.22235

9. Wang, Z. W., Lee, S. H., Elkins, J. G., Li, Y., Hamilton-Brehm, S., \& Morrell-Falvey, J. L. (2013). Continuous live cell imaging of cellulose attachment by microbes under anaerobic and thermophilic conditions using confocal microscopy. Journal of Environmental Sciences (China), 25(5), 849-856. https://doi.org/10.1016/S10010742(12)60104-1

10. Travis, A. J., Murison, S. D., Perry, P., \& Chesson, A. (1997). Measurement of cell wall volume using confocal microscopy and its application to studies of forage degradation. Annals of Botany, 80(1), 1-11. https://doi.org/10.1006/anbo.1997.042

11. Coletta, V. C., Rezende, C. A., Da Conceicao, F. R., Polikarpov, I., \& Guimaraes, F. E. G. (2013). Mapping the lignin distribution in pretreated sugarcane bagasse by confocal and fluorescence lifetime imaging microscopy. Biotechnology for Biofuels, 6(1), 1-10. https://doi.org/10.1186/1754-6834-6-43

12. Fromm, J., Rockel, B., Lautner, S., Windeisen, E., \& Wanner, G. (2003). Lignin distribution in wood cell walls determined by TEM and backscattered SEM techniques. Journal of Structural Biology, 143(1), 77-84. https://doi.org/10.1016/S10478477(03)00119-9

13. Ballard, D. H., Alexander, J. S., Weisman, J. A., Orchard, M. A., Williams, J. T., \& D'Agostino, H. B. (2015). Number and location of drainage catheter side holes: In vitro evaluation. Clinical Radiology, 70(9), 974-980. https://doi.org/10.1016/j.crad.2015.05.004

14. Sant'Anna, C., \& Souza, W. De. (2012). Microscopy as a Tool to Follow Deconstruction of Lignocellulosic Biomass. Current Microscopy Contributions to Advanced in Science and Technology, 639645. https://doi.org/10.1007/s11136-0110045-y

15. Tapen M Mukherjee, B. D. (1993). Diagnostic Electron Microscopy Procedure. Microscope Society of America..

16. Xu, F., Zhong, X. C., Sun, R. C., \& Lu, Q. (2006). Anatomy, ultrastructure and lignin distribution in cell wall of Caragana Korshinskii. Industrial Crops and Products, 24(2), 186-193. https://doi.org/10.1016/j.indcrop.2006.04.00 2

17. Pingali, S. V., Urban, V. S., Heller, W. T., McGaughey, J., ONeill, H., Foston, M., ... Evans, B. R. (2010). Breakdown of cell wall nanostructure in dilute acid pretreated biomass. Biomacromolecules, 11(9), 2329_ 2335. https://doi.org/10.1021/bm100455h 
